\title{
Identification of Roof Shapes that Suitable for Buildings on Bangunharjo Street Corridor According to Public Perception
}

\author{
Anashia Merliana Satriani, Maria Immaculata Ririk Winandari \\ Department of Architecture, Universitas Trisakti, Indonesia
}

Corresponding e-mail: anashia.satriani@yahoo.co.id

Article info:

Received: 14-08-2019, Revised: 09-09-2019, Accepted: 10-09-2019

\begin{abstract}
Physical elements are the most easily observed and give visual impression that can absorbed by human memory. Physical element is formed by row of façade elements. Roof is the one of façade elements that very dominant form character. Bangunharjo is a corridor that dominant by residental functions in Semarang, Indonesia. Commercial demands and land efficiency make change to façade. Some of these changes adjust according to the perceptions of designers and buiding owners. But, the suitability of building and shape of façade elements must be assessed according to public perceptions. This study aims to find the shape of façade elements, especially roofs which suitable for Bangunharjo street corridor according public perception. The method of discussion is a quantitative method with a visual perception approach. For the result of the analysis it was found that the roof shape that most suitable for buildings on Bangunharjo is pelana (saddle roof) and limasan (pyramid roof).
\end{abstract}

Keywords: Roof, Bangunharjo, Corridor, Public perception

\section{Introduction}

Semarang located on the coast of the North Coast of Java, is one of the largest port cities on the Java Island. Development of Semarang started from trading activities. The traders who anchored then forming urban villages based on group that according by ethnicity, jobs or race. One of the city villages is Kampung Kauman (Widiastuti, Rahmat \& Aseani, 2015). Kampung Kauman is a village which the center of development Islam religion, within Perda (Region Regulation) of Semarang City No.14, 2011 explained that Kampung Kauman is one of Cultural Heritage Area. One of corridor that become the main access is Bangunharjo Street. Bangunharjo is a corridor that dominant by residental, but along times commercial demands, land efficiency cause some buildings along Bangunhajo street changes. Some of changes are suitable but there are also contrasts with other buildings (Wijanarko,2001; Sukawi, 2009). Some of these changes adjust according to the perceptions of designers and buiding owners. But, the suitability of building and shape of façade elements must be assessed according to public perceptions. Research on suitability building for Bangunharjo street corridor according to public perceptions is able to reflect an identity and will be useful as urban design guidliness.

\section{Methods}

This research uses a quantitative method with a visual perception approach. Visual perception is to the perception of the physical environment visually. To get information objectively this study uses respondents from two groups.

The research location is in Bangunharjo Street Kauman Semarang. Sampling technique is done by dividing into segments which are then obtained by 3 segments which are divided into 2 sides. 


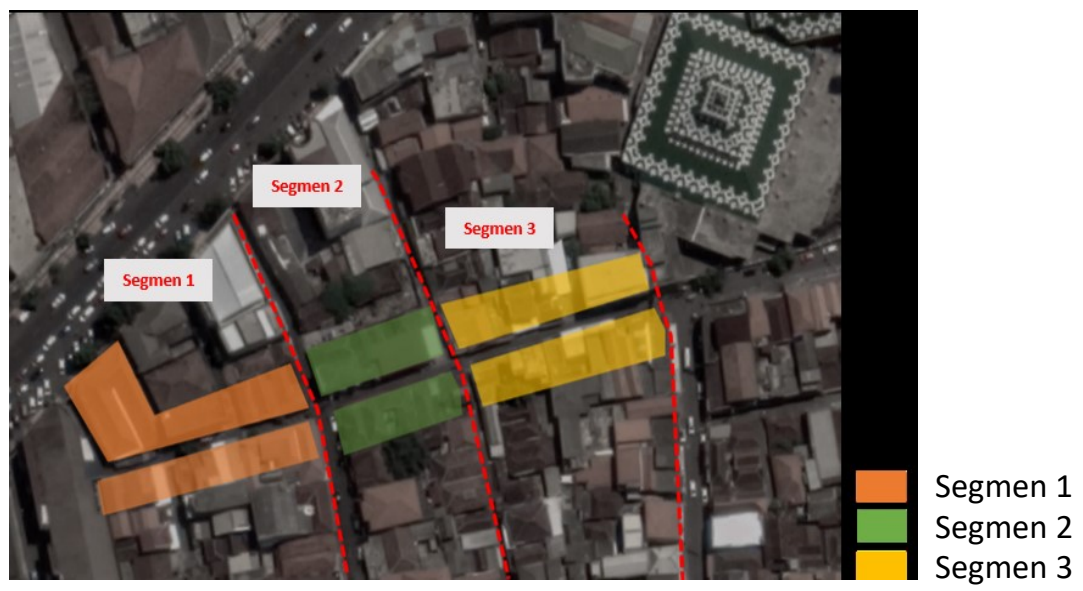

Figure 2.1. Bangunharjo street Segmentation (author, 2019)

The are 4 main steps, first determining the research case (the stages of making questionnaire), for second step is interview process, then comparison of the result of public perception with criteria of Kampung Kauman building, and for the last is making conclusions.

\subsection{Determining The Research Case}

The step that that must to do is selection of architectural elements, this selection was obtained through literature review, after it conducted an initial survey to capture the entire roof shape of buildings on Bangunharjo street which is then typologized based on the style. These results are used as a reference in making a questionnaire.

\subsection{Interview Process}

Selection of respondents is based on background knowledge about architecture. Respondents are grouped into two, the first group is the group of common the who have minimal knowledge of architecture. The second group is the group of experts from among those who understand architecture. Determination of the number of samples according to Slovin is $n=N / 1+N d^{2}$. So, $n$ obtained by 35 respondents, so it takes a total of 70 respondents. All groups of respondents must have visited or had activities on Bangunharjo street.

Interviews were conducted in writing using the Likert scale reference with 5 levels namely strongly agree (5), agree (4), doubt (3), disagree (2) and strongly disagree (1). In this sectin expert and common respondents are asked to rate the suitability and incompability of the roof elements. The ara several pictures that represent the roof shape of the building on Jalan Bangunharjo.

\subsection{Comparison of the Result of Public Perception with Architectural Characteristic of Kampung Kauman Builiding}

In this stage the results obtained from expert and common respondents were concluded so as to produce a public perception. Then the public perceptionis compared with the criteria of Kampung Kauman buildings. Architectural Charateristic of kampung Kauman, Semarang influenced by historical development. That can be seen in this timeline: 


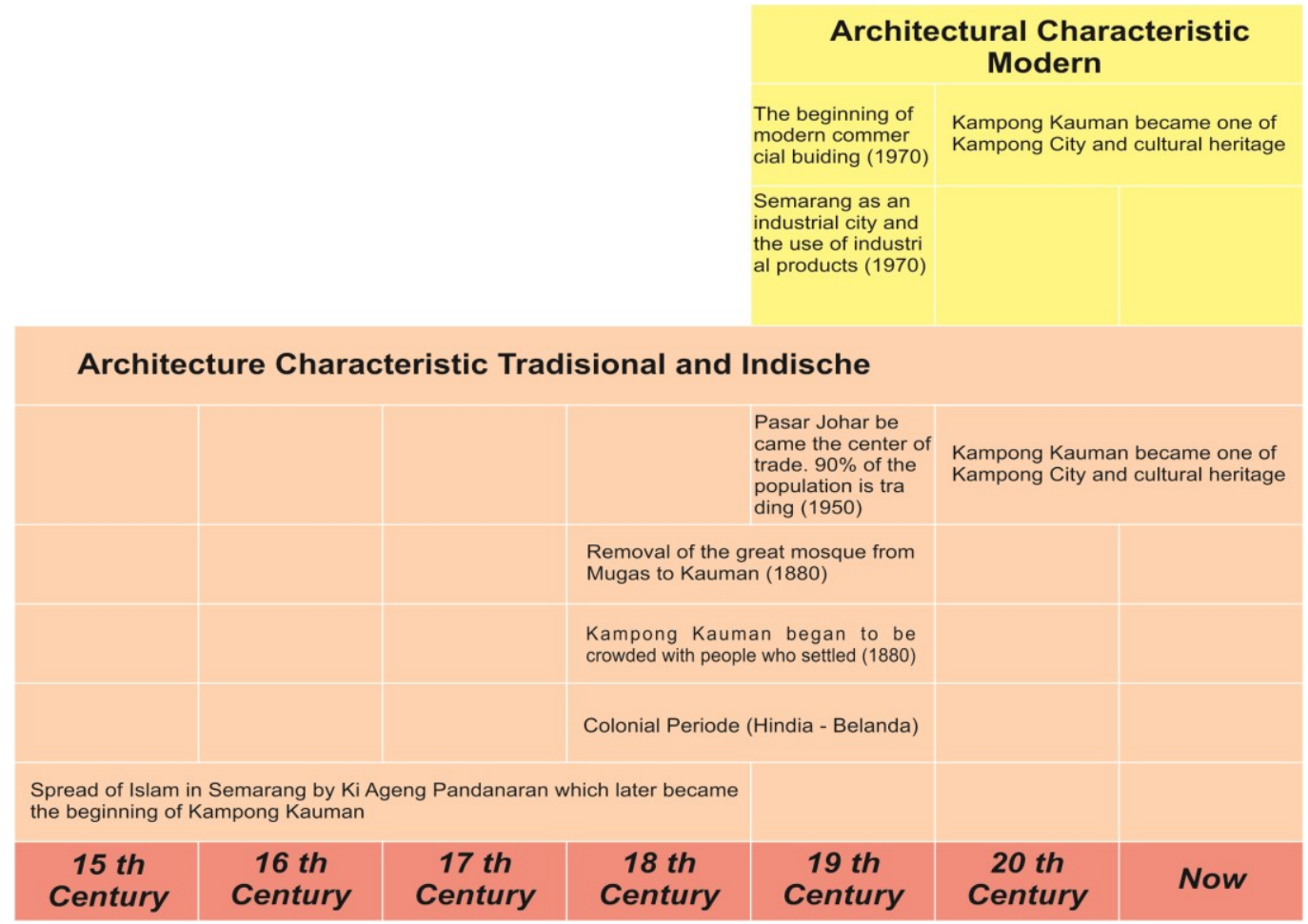

Figure 2. 1 Historical timeline of Kampung Kauman

Variety of architectural characteristic which is used in buildings in Kampung Kauman can be concluded as in the following table:

Table 2. 1 Architectural Characteristic In Kampong Kauman Semarang (Budiharjo, 1997; Listianti, 1999; Soekirman, 2000; Wijanarko, 2001; Sumalyo, 2005; Sukawi, 2009)

\begin{tabular}{|c|c|c|c|}
\hline $\begin{array}{l}\text { Fasade } \\
\text { Element }\end{array}$ & Architecture Indische & Architecture Traditional & $\begin{array}{l}\text { Architecture } \\
\text { Modern }\end{array}$ \\
\hline $\begin{array}{l}\text { Roof } \\
\text { shape }\end{array}$ & $\begin{array}{l}\text { Limasan shape (typical } \\
\text { residential roof) }\end{array}$ & $\begin{array}{l}\text { Limasan and Pelana shape. Pelana } \\
\text { shape are more use }\end{array}$ & Flat roof shape \\
\hline \multirow[t]{2}{*}{ Ornament } & $\begin{array}{l}\text { The existence of a vent that } \\
\text { also serves as a regulation of } \\
\text { air circulation }\end{array}$ & $\begin{array}{l}\text { Tritisan ornaments are on carved } \\
\text { terrace made of wood which leads } \\
\text { to flora. }\end{array}$ & \\
\hline & & $\begin{array}{l}\text { There is a vent that is placed above } \\
\text { the door. Semarangan patterned } \\
\text { motifs are tendrils of rolls, leaves, } \\
\text { flowers, animals and even Islamic } \\
\text { nuances such as the use of } \\
\text { calligraphy motifs. }\end{array}$ & No ornament \\
\hline $\begin{array}{l}\text { Doors } \\
\text { and } \\
\text { Windows } \\
\text { shape }\end{array}$ & $\begin{array}{l}\text { The door consists of two } \\
\text { doors, where the first layer } \\
\text { door uses wood material and } \\
\text { the second layer door uses } \\
\text { material that uses glass } \\
\text { panels and not infrequently } \\
\text { also used trellis }\end{array}$ & $\begin{array}{l}\text { The number of entrances is three. } \\
\text { The traditional door model typical of } \\
\text { Semarangan is a double door that is } \\
\text { an opening consisting of a pair of } \\
\text { doors inside and out. The outer door } \\
\text { is usually made of wood panels } \\
\text { while the inside door is made of } \\
\text { glass. Motifs that are often found } \\
\text { are simple carving shapes such as } \\
\text { the sun, ellipses and rectangles }\end{array}$ & $\begin{array}{l}\text { Rectangular } \\
\text { window shape }\end{array}$ \\
\hline
\end{tabular}




\begin{tabular}{l|l|l|l}
\hline $\begin{array}{l}\text { Fasade } \\
\text { Element }\end{array}$ & Architecture Indische & Architecture Traditional & $\begin{array}{c}\text { Architecture } \\
\text { Modern }\end{array}$ \\
\hline $\begin{array}{l}\text { Console } \\
\text { Shape }\end{array}$ & & $\begin{array}{l}\text { Console is usually made of wood or } \\
\text { iron, decorative motifs such as } \\
\text { tendrils, tumpal, kawung, flowers, } \\
\text { etc. }\end{array}$ & $\begin{array}{l}\text { No ornament } \\
\text { nillboards }\end{array}$ \\
$\begin{array}{l}\text { Use of } \\
\text { no use of billboards }\end{array}$ & $\begin{array}{l}\text { There is the } \\
\text { use of } \\
\text { billboards in } \\
\text { buildings with } \\
\text { commercial } \\
\text { functions }\end{array}$ \\
\hline
\end{tabular}

Source: Author, 2019

So, it can be conclude, the roof shape that suitable with the architectural character of Kauman Semarang for the corridor of Bangunharjo Street Kauman Semarang is Pelana and Limasan (Listianti, 1999; Wijanarka, 2001, Sukawi, 2009)

\subsection{Making Conclusion}

For the last researchers, draw conclusions about the suitable roof elements for Bangunhajo street Kauman Semarang

\section{Result and Discussion}

Object of research is in Kampung Kauman Semarang or known as Santri Village in Semarang. Kampung Kauman is a village that was originally inhabited by Santri from Ki Ageng Pandan Arang and also is the center of development Islam religion. Administratively, Kauman Semarang Semarang is located in the district of Central, with the following boundaries:

Northern : Alun-alun Barat street

East side : Kanjengan shops, Alun-alun Barat street

Southern : Shopping Street KH. Wahid Hasyim

West side : Kampung Jonegaran, Bangunharjo

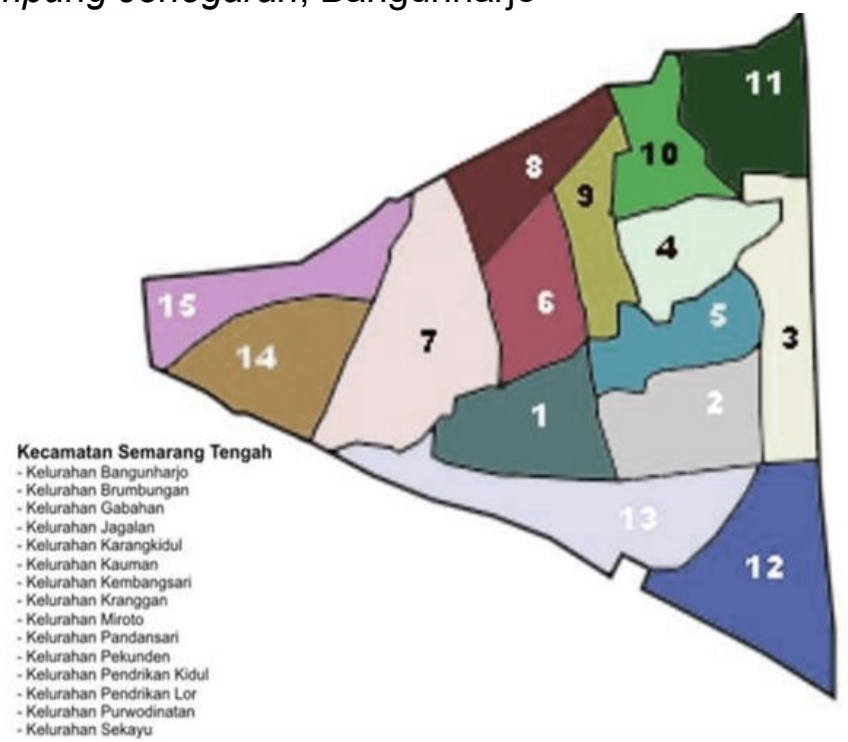

Figure 3.1. Central Semarang District (Semarang Tengah Dalam Angka, 2019) 


\subsection{Respondent Description}

Respondents numbered 70 people consisting of 2 groups, namely the Expert group (Under graduate Students, Postgraduate Students) and the Common Group (Traders and Residents). The description of respondent data can be seen in Table 3.1

Table 3.1. Respondent Data (author, 2019)

\begin{tabular}{|c|c|c|c|c|c|}
\hline \multirow[t]{2}{*}{ No } & \multirow[t]{2}{*}{ Information Of } & \multicolumn{2}{|c|}{ Number of Respondents } & \multirow{2}{*}{$\begin{array}{c}\text { Total } \\
\text { Amount }\end{array}$} & \multirow{2}{*}{$\begin{array}{c}\text { Percentage } \\
(\%)\end{array}$} \\
\hline & & Expert & Common & & \\
\hline \multirow[t]{3}{*}{1} & Domicile & & & & \\
\hline & Semarang & 38 & 32 & 70 & 100 \\
\hline & $\begin{array}{l}\text { Outside of } \\
\text { Semarang }\end{array}$ & 0 & 0 & 0 & 0 \\
\hline \multirow[t]{5}{*}{2} & Age & & & & \\
\hline & $\leq 20$ years & 5 & 3 & 8 & 11.43 \\
\hline & $\begin{array}{l}20<\mathrm{x} \leq 30 \\
\text { years }\end{array}$ & 25 & 9 & 34 & 48,57 \\
\hline & $\begin{array}{l}30<\mathrm{x} \leq 40 \\
\text { years }\end{array}$ & 6 & 16 & 22 & 31.43 \\
\hline & 40 years $<x$ & 2 & 4 & 6 & 8.57 \\
\hline \multirow[t]{6}{*}{3} & Education & & & & \\
\hline & SMP & 0 & 6 & 6 & 8.57 \\
\hline & SMA & 0 & 21 & 21 & 30.00 \\
\hline & Diploma & 0 & 5 & 5 & 7.13 \\
\hline & Bachelor & 22 & 0 & 22 & 31.43 \\
\hline & Master Degree & 16 & 0 & 16 & 22.87 \\
\hline \multirow[t]{6}{*}{4} & Job & & & & \\
\hline & Student & 30 & 0 & 30 & 42.87 \\
\hline & Entrepreneur & 0 & 14 & 14 & 20.00 \\
\hline & Employee & 8 & 7 & 15 & 21.43 \\
\hline & Laborer & 0 & 7 & 7 & 10.00 \\
\hline & Housewife & 0 & 4 & 4 & 5.70 \\
\hline \multirow[t]{3}{*}{5} & Gender & & & & \\
\hline & Male & 16 & 19 & 35 & 50.00 \\
\hline & Female & 22 & 13 & 35 & 50.00 \\
\hline
\end{tabular}

Source: Author, 2019

\subsection{Roof Shape}

Observation on suitable roof shape for buildings on Bangunharjo street were made through selection of pictures / photos of the roof which had been typologically based on the style. This shape consists of 6 types. Which is then assessed using likert scale based on common and expert perception.
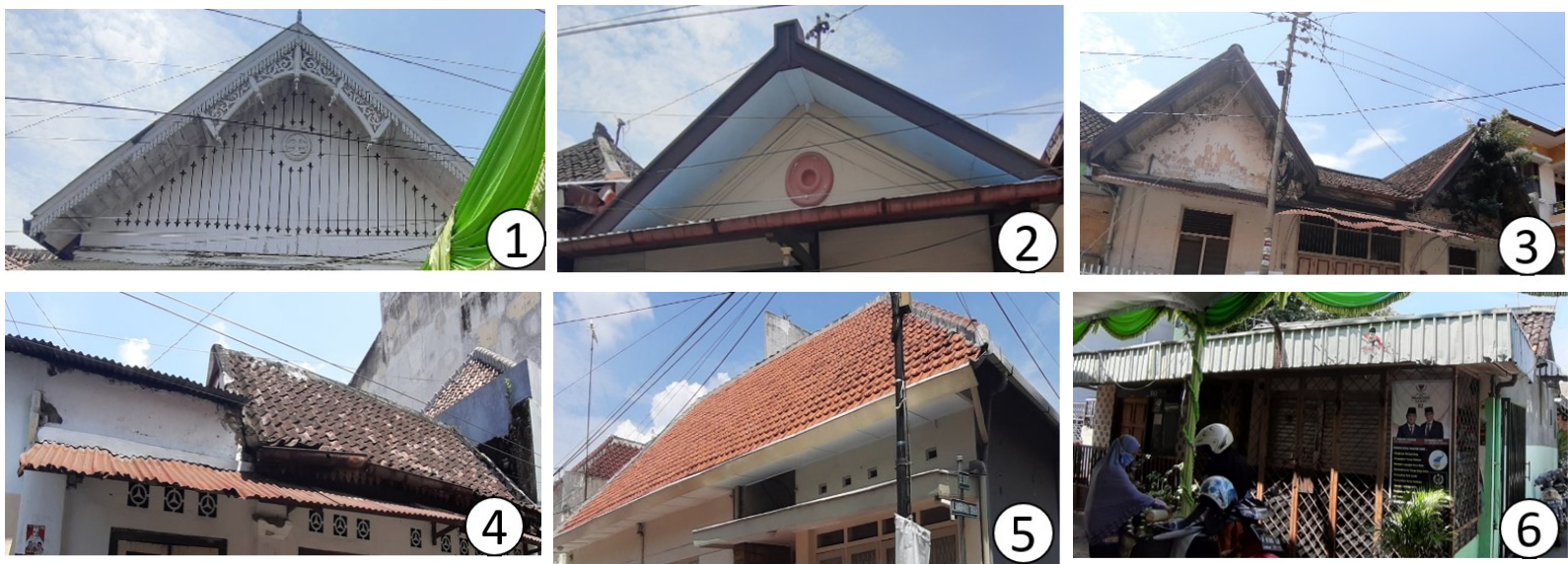

Figure 3.2. Typology of Building Roofs on Bangunharjo street (author, 2019) 
To assess the suitable of roof shape of Building on Bangunharjo, Kauman Semarang. Comparasion should be made between assessment result of the expert and common group. Detail of the assessment for the suitable roof shape on Bangunharjo, can be seen in Table 3.2 and Figure 3.3

Table 3.2. Assessment Result the Suitable Roof Shape (author, 2019)

\begin{tabular}{lcccccc}
\hline \multicolumn{1}{c}{ Group } & \multicolumn{7}{c}{ Roof Shape } \\
& $\mathbf{1}$ & $\mathbf{2}$ & $\mathbf{3}$ & $\mathbf{4}$ & $\mathbf{5}$ & $\mathbf{6}$ \\
\hline Expert Group & 4.11 & 4.03 & 2.87 & 2.53 & 3.87 & 2.24 \\
Common Group & 4.13 & 4.07 & 2.65 & 2.27 & 3.71 & 2.55 \\
Total & $\mathbf{4 . 1 2}$ & $\mathbf{4 . 0 5}$ & $\mathbf{2 . 7 6}$ & $\mathbf{2 . 4}$ & $\mathbf{3 . 7 9}$ & $\mathbf{2 . 3 6}$ \\
\hline
\end{tabular}

Source: Author, 2019

Based on the table above, the responses among the respondents groups to the roof shape selection, both the expert group and the common group stated that the roof shape 1, roof shape 2, and roof shape 5 are suitable. Whereas for the incompatible form is the roof 6 . For the roof 3 and the overall roof 4 is considered normal

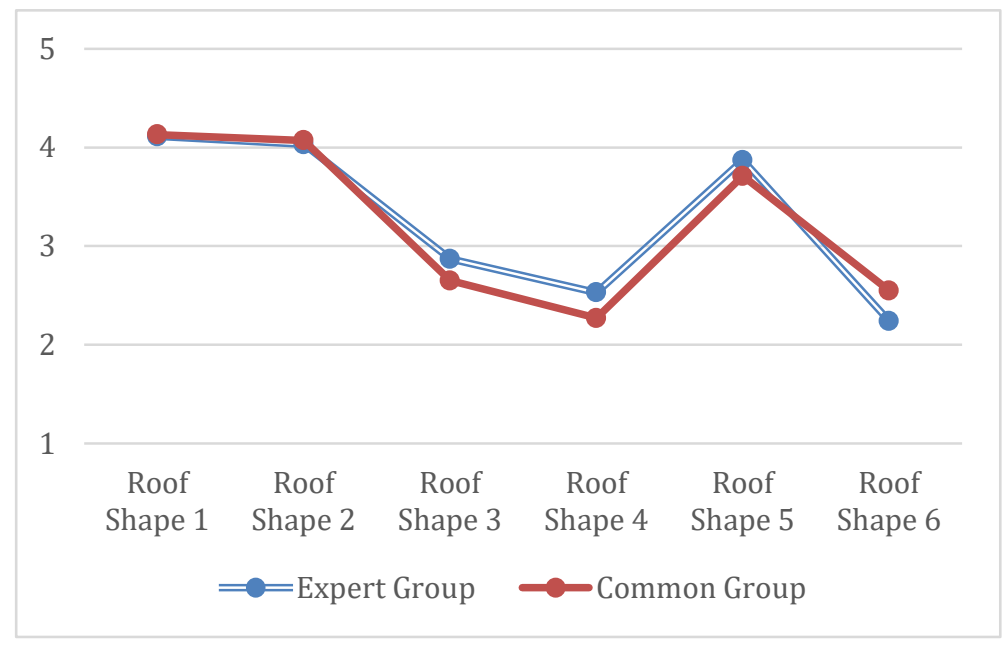

Figure 3.3. Roof Shape Mean Diagram (author, 2019)

Roof Form 1 is a roof with a pelana shape, most of the buildings on Bangunharjo use this pelana shape. The shape of the roof is stated to be appropriate by all groups of experts and common with the highest average number of 4.19 (appropriate). The Roof Form 2 has a basic shape that is not different from the roof shape 1 which is the pelana shape. The shape of the roof 2 is suitable by expert groups and common groups. And also, the shape of the roof 5 has the shape of the limasan, the shape of the roof 5 is also considered appropriate by the two groups of respondents.

Roof Form 3 and 4 have the form of a double pelana, this form is considered not suitable by the two groups of respondents. The lowest average value was found on the roof form 6 with an average value of 2.36 (not appropriate). The shape of the type 6 roof is a modification of the shape of the limasan roof that combined with the flat roof. Almost all groups of respondents both expert and common stated that the shape of the roof was not suitable for buildings on Bangunharjo street. 


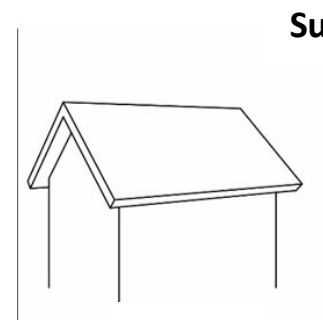

Type 1
Suitable

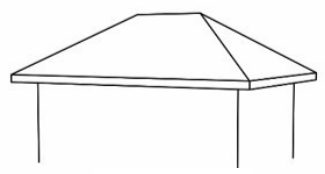

Type 3

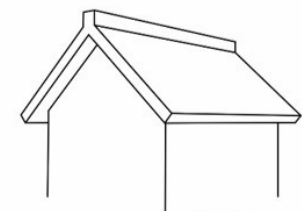

Type 2

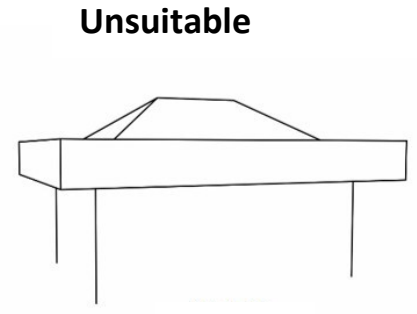

Type 6

Figure 3.4. Suitable and Unsuitable Roof Forms (author, 2019)

Concluded that according to the responses of the two groups of respondents both experts and common the form of a roof suitable for buildings on Bangunharjo street was a roof with a Pelana shape and a Limasan shape. The criteria of roof shape also has similarities with the theory stated by Listianti, 1999; Wijanarka, 2001; Sukawi, 2009

\section{Conclusion}

Conclusion of public perceptions regarding the form of a roof that is suitable for buildings on Bangunharjo street corridor, Kauman, Semarang is pelana shape and limasan shape that reflects the indisce and traditional architectural characters. A lot of Pelana and limasan roofs is closely related to Jalan Bangunharjo which is dominated by residential functions.

For architect, in the process of designing new buildings along Bangunharjo street, Kauman Semarang should pay attention to the visual appearance that is adjusted / based on the existing facade elements which are based on traditional or indische styles. So the presence of the new building can be in harmony with the environment.

\section{References}

Budiharjo, Eko. (1997). Arsitektur Pembangunan dan Konservasi. Jakarta: Djambatan

Listianti, Etty Endang. (1999) . Rumah tinggal kampung Kauman Semarang : Kajian kualitas arsitektural bangunan rumah tinggal. Yogyakarta: Universitas Gajah Mada

Region Regulation of Semarang City, Perda Kota Semarang No.14 Tahun 2011 Kebijakan Tata Ruang Wilayah Kota

Sukawi. (2009). Pengaruh Arsitektur Indis Pada Rumah Kauman Semarang. Jurnal Tesa Arsitektur, Volume 7 Nomor 1 Juni 2009. Unika: Semarang

Sumalyo, Yulianto. (2005). Perkembangan Arsitektur Modern Awal Abad X1X Sampai dengan XX. Unversitas Gajah Mada Press

Widiastusi, R. Rahmat A \& Aseani, W. 2015. Conservation and Revitalitation in Semarang Chinatown (Klenteng "Chinese Shrine" as Phsycal Characteristic in Semarang Chinatown. Procedia Enviromental Sciences, 28, hal: 549-556

Wijanarko. 2001. Teori Desain Kawasan Bersejarah. Semarang: Universitas Palangkaraya 